advised on statistical evaluation. One of us (A.D.T.) was in receipt of a University of Edinburgh Faculty of Medicine Graduate Research Scholarship.

\section{REFERENCES}

Baker, H., Herbert, V., Frank, O., Pasher, I., Hutner, S. H., Wasserman, L. R., and Sobotka, H. (1959). Clin. Chem., 5, 275. Chanarin, I., Mollin, D. L., and Anderson, B. B. (1958). Brit. \%. Haemat., 4, 435.

Cowan, J. D., Hoffbrand, A. V., and Mollin, D. L. (1966). Lancet, 1, 11. Forshaw, J., Moorhouse, E. H., and Harwood, L. (1964). Ibid., 1, 1004. (1965). Ibid., 1, 275.
Girdwood, R. H. (1960a). Advanc. clin. Chem., 3, 235.

- (1960b). Scot. med. F., 5, 10.

(1964). Lancet, 1, 1277.

- and Delamore, I. W. (1961). Scot. med. 7., 6, 44

Gough, K. R., Read, A. E., McCarthy, C. F., and Waters, A. H. (1963), Quart. 7. Med., 32, 243.

Hurdle, A. D. F., and Williams, T. C. P. (1966). Brit. med. F., 2, 202.

Kohn, J., Mollin, D. L., and Rosenbach, L. M. (1961). F. clin. Path. $14,345$.

Read, A. E., Gough, K. R., Pardoe, J. L., and Nicholas, A. (1965). Brit. med. Э., 2, 843 .

Varadi, S., and Elwis, A. ((1964). Lancet, 1, 1162.

Waters, A. H., and Mollin, D. L. (1961). ł. clin. Path., 14, 335.

\title{
Simultaneous Administration of Live Measles Virus Vaccine and Smallpox Vaccine
}

\author{
P. M. SHERMAN,* M.B., B.S., D.C.H. ; R. G. HENDRICKSE,* M.D., F.R.C.P.ED. \\ D. MONTEFIORE,* M.D., DIP.BACT., M.C.PATH ; T. PERADZE, $\dagger$ M.D. ; G. COKER,* F.I.M.L.T.
}

Brit. med.7., 1967, 2, 672-676

Smallpox has been virtually eradicated from Europe and America by means of efficient control measures practised over many years. The disease is, however, still prevalent in large areas of Africa and Asia, and the possibility of global eradication was discussed by an expert committee of the World Health Organization (W.H.O., 1964).

Measles is also a serious disease in developing countries (Gans et al., 1961 ; Morley et al., 1963; Hendrickse and Sherman, 1965), having many clinical similarities to the illness as seen in Europe in the early part of the present century (Morley, 1964).

During the past few years methods of active immunization against measles have been developed (W.H.O., 1963). Much emphasis has been placed on the use of live vaccines, and there have been numerous reports on the use of the attenuated types of measles vaccines (Collard et al., 1961 ; Hendrickse et al., 1964 ; Krugman, 1965 ; Smorodintsev et al., 1965 ; Rey et al., $1965 \mathrm{~b})$, as well as on the comparison between attenuated and further attenuated vaccine strains with regard to clinical reactions and serological response (Du Pan, 1965 ; Hendrickse et al., 1964, 1965, 1966a, 1966b).

Satisfactory results have been reported from Senegal and Nigeria in trials of further attenuated measles vaccines administered by needleless injectors (Rey et al., 1965a ; Hendrickse et al., 1966a). It is clear that this method of injection would be required in any large-scale vaccination programme.

Plans for the eradication of smallpox and the control of measles in the near future, in 19 West African countries, "spcnsored by the U.S. Government in co-operation with the World Health Organization," announced recently in the Nigerian press (New Nigeria, 1966 ; Daily Times, 1966), bring the problem of the simultaneous use of measles and smallpox vaccines to the forefront.

Meyer et al. (1964) reported on the response of 545 children in the Upper Volta who were given combined measles, smallpox, and yellow fever vaccines, which were physically mixed before being used in a single injection. They gave little detailed

- From the Departments of Paediatrics and Bacteriology, and the Institute of Child Health, University of Ibadan.

t On secondment by W.H.O. from the Pasteur Institute, Leningrad. information about the clinical responses to the procedure apart from that concerning febrile responses and rashes. Budd et al. (1965) evaluated measles and smallpox vaccines administered simultaneously to 258 children in Togoland ; information, however, is not available at present whether or not the vaccines were physically mixed. The attenuated Enders B strain of measles vaccine was used in both trials.

The results of the trials indicated that antibody responses were good, but were accompanied by a high rate of severe febrile reactions. Similar trials have not been carried out in other West African territories, nor has there been a direct comparison between the responses to attenuated and further attenuated measles vaccine when given simultaneously with smallpox vaccine.

If developing countries are to embark on mass smallpox' measles vaccination campaigns information is urgently needed regarding the nature of reactions that are likely to follow the procedure. We need also to know which of the live measles vaccines currently available are most suitable for use in such a campaign in developing African countries.

In an attempt to answer these questions a clinical trial in children was undertaken in a town in Western Nigeria. In this trial one group was given attenuated measles vaccine plis smallpox vaccine; a second group was given further attenuated measles vaccine plus smallpox vaccine; and a third group, which acted as controls, was given smallpox vaccine only. Our aim was to determine the pattern of reaction to the simultaneous vaccination procedure, including antibody responses, and to discover whether there were any significant differences between reactions provoked by the attenuated or further attenuated measles vaccines when given with smallpox vaccine. We report here the results of the trial.

\section{Material and Methods}

The study was undertaken at Ipetu Ijesha, a town of some 43,000 to 47,000 persons, situated about 97 miles (156 km.) from Ibadan, in the Western Provinces of Nigeria.

Healthy children between the ages of 6 months and 3 years who had had neither measles nor smallpox vaccination were 
invited to attend for a simultaneous measles/smallpox vaccination. The' children were preregistered on unnumbered cards; the name, age, sex, and address of each child were recorded by local personnel in the week before the day of vaccination.

On the day of vaccination-all the children attending were screened by experienced nursing staff, and those considered unfit for vaccination were excluded. The registration cards of those accepted into the trial were numbered serially.

The children were divided into three groups: (1) smallpox vaccine only; (2) smallpox vaccine plus further attenuated measles vaccine (Beckenham 31 ; Wellcovax), referred to as the Wellcovax group; and (3) smallpox vaccine plus attenuated measles vaccine (Enders B type; Rubeovax Lyovac), referred to as the Rubeovax group. All children in the combined smallpox plus measles groups had blood samples taken before vaccination and on the 21 st day after vaccination.

\section{Vaccines and Vaccination Procedure}

The smallpox vaccine came from the Lister Institute and was supplied in ampoules containing enough material for 25 vaccinations by the multiple-pressure technique. The material in each ampoule was reconstituted in the diluent supplied and then made up to $3 \mathrm{ml}$. with normal saline. The vaccine was administered by Dermojet, which delivers approximately 0.07 $\mathrm{ml}$. per dose. The number of pock-forming units in $0.1 \mathrm{ml}$. was about $10^{6}$. An average of 40 doses was obtained from each ampoule. Smallpox vaccine was given in the deltoid area of the left arm.

The attenuated measles vaccine used was the Enders B type vaccine (Rubeovax Lyovac). This was in single-dose ampoules which were reconstituted with $0.7 \mathrm{ml}$. of diluent supplied by the manufacturers ; $0.5 \mathrm{ml}$. of the reconstituted vaccine contained a dose of $1,000 \mathrm{TCID}_{50}$ and was given subcutaneously by syringe and needle into the upper outer quadrant of the buttock.

The further attenuated measles vaccine used was Beckenham 31 vaccine (Wellcovax), supplied in multidose containers. The vaccine was reconstituted with distilled water so that a dose of $1,000 \mathrm{TCID}_{50}$ was contained in $0.2 \mathrm{ml}$. This was delivered by Ped-O-Jet needleless injector subcutaneously into the upper outer quadrant of the buttock.

\section{Follow-up}

1. After vaccination the registration card was taken from the patient and an appointment card bearing the same number was issued. An instruction sheet containing details of the followup procedure was also given to the mothers. All children received a curative dose of chloroquine on the day of vaccination, and pyrimethamine one week later.

2. The follow-up days were the 5 th, 7 th to 12 th inclusive, and the 21st after vaccination. All children who were unwell on the 12th day were seen again on the 13th or 14th day.

3. At each attendance rectal temperatures were taken, and any complaints or abnormal physical findings were recorded on a special card. Follow-up was undertaken by one medical officer and two experienced health visitor/nursing sisters. Any child seen by the nursing sisters with fever of over $101^{\circ} \mathrm{F}$. $\left(38.3^{\circ} \mathrm{C}\right.$.) or with special conditions was referred to the medical officer. Children who were unwell were treated according to the findings. No child was given chloroquine unless a blood film had been taken for examination to exclude the possibility of a malarial infection causing pyrexia.

4. The personnel responsible for follow-up took no part in the actual vaccination procedure, and were kept unaware of the vaccination status of the children.
5. Any child who developed a serious complaint was referred to the Wesley Guild Hospital, Ilesha, where the medical superintendent had a copy of the vaccination code.

\section{Antibody Studies}

Finger-prick blood samples were taken on to filter paper discs on the day of vaccination and on the 21 st postvaccination day. Paired samples were eluted and measles antibodies were determined by the haemagglutination inhibition method (Hendrickse et al., 1966b).

\section{Assessment of Clinical Reactions}

On the 15th postvaccination day the records of all children in the trial who had satisfied follow-up requirements were scrutinized by two physicians. From the data recorded an assessment was made whether or not the subjects had shown evidence of a measles-like illness and whether they had been well or unwell. The reasons for assessing a child as unwell were recorded. In order to avoid any bias in this assessment, the record cards were shuffled to break the numerical sequence, and the serial number on each card was kept concealed until after the assessors had recorded their assessment.

\section{Results}

Table I gives details of numbers in each group, number of defaulters, and mean age of patients.

TABLE I.-Numbers of Children Vaccinated and Clinically Assessed

\begin{tabular}{|c|c|c|c|}
\hline & $\begin{array}{c}\text { Rubeovax } \\
\text { Group }\end{array}$ & $\begin{array}{l}\text { Wellcovax } \\
\text { Group }\end{array}$ & $\begin{array}{l}\text { Smallpox } \\
\text { Only } \\
\text { Group }\end{array}$ \\
\hline $\begin{array}{llll}\text { Total in group.. } & \ldots & \ldots & \ldots \\
\text { No. defaulting } . & \\
\text { No. included in clinical assessment } & .\end{array}$ & $\begin{array}{r}98 \\
5 \\
93\end{array}$ & $\begin{array}{r}101 \\
2 \\
99\end{array}$ & $\begin{array}{r}50 \\
5 \\
45\end{array}$ \\
\hline \multirow[t]{3}{*}{ Mean age (months) } & $17 \cdot 1$ & $16 \cdot 7$ & $17 \cdot 6$ \\
\hline & Analysis of & ever & \\
\hline & $\underset{\substack{\text { Group } \\
\text { (93) }}}{\text { Rubeovax }}$ & $\begin{array}{c}\text { Wellcovax } \\
\text { Group } \\
\text { (99) }\end{array}$ & $\begin{array}{l}\text { Smallpox } \\
\text { Only Group } \\
\text { (45) }\end{array}$ \\
\hline 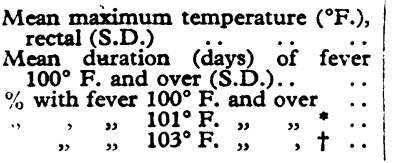 & $\begin{array}{l}102(1 \cdot 4) \\
4 \cdot 3(1 \cdot 7) \\
95 \cdot 7 \\
71 \cdot 0 \\
29 \cdot 0\end{array}$ & $\begin{array}{l}101.3(1 \cdot 2) \\
3.7(1.8) \\
93.9 \\
53.5 \\
10.1\end{array}$ & $\begin{array}{l}100 \cdot 9(1 \cdot 2) \\
2.9(2 \cdot 2) \\
91 \cdot 1 \\
37 \cdot 7 \\
8.9\end{array}$ \\
\hline
\end{tabular}

* S.E.D. between the Rubeovax and the Wellcovax groups $6.87(\mathrm{P}<0.05)$.
t S.E.D. between the Rubeovax and the Wellcovax groups $5.88(\mathrm{P}<0.01)$.

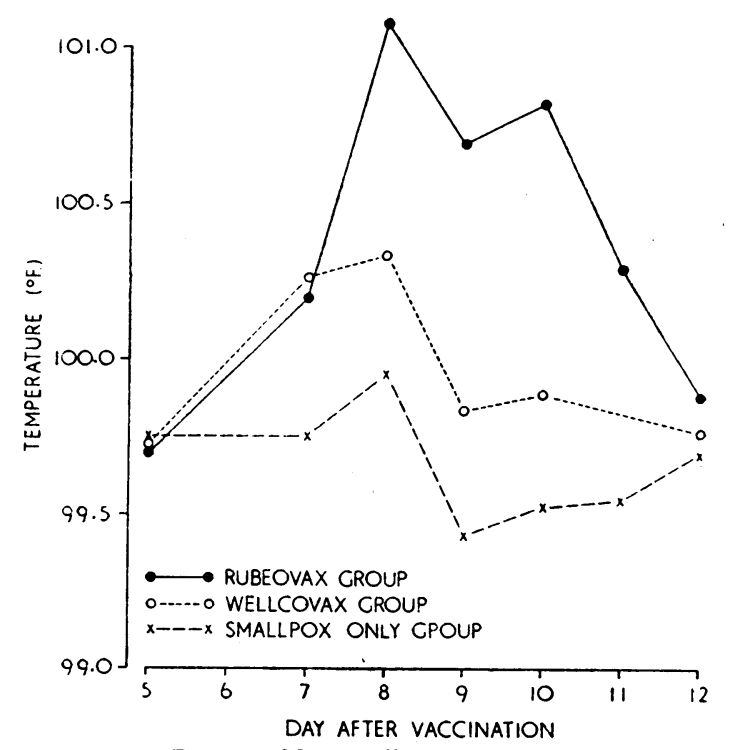

FIG. 1.-Mean daily temperatures. 


\section{Temperature Responses}

Table II and Figs. 1, 2, and 3 give details of temperature responses in the three groups. The following points are worthy of note:

1. Daily mean temperatures were significantly higher in the Rubeovax group than in the Wellcovax group and the control group (Fig. 1).

2. When the daily mean temperatures are plotted showing two standard deviations of the mean for the Rubeovax and Wellcovax groups, there is a statistically significant difference between the two groups (Fig. 2).

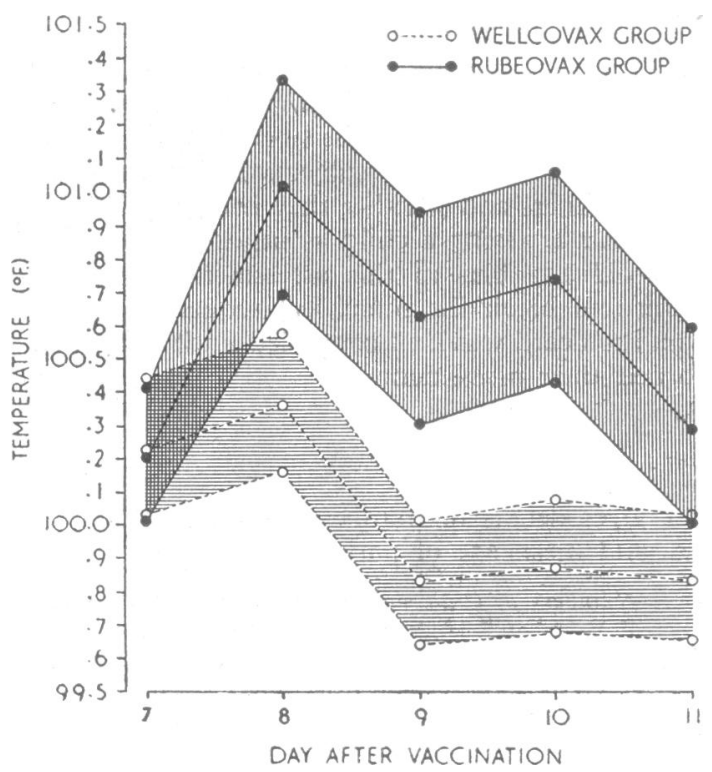

FIG. 2.-Mean daily temperatures, showing the standard deviations of the means (hatched areas indicate two standard deviations from means).

3. The incidence of pyrexia of $101^{\circ} \mathrm{F} .\left(38.3^{\circ} \mathrm{C}\right.$.) or over was significantly higher in the Rubeovax group than in the Wellcovax group $(\mathbf{P}<0.05)$. The difference between these two groups is even more pronounced when considering temperatures of $103^{\circ} \mathrm{F}$. $\left(39.4^{\circ}\right.$ C.) or more $(\mathrm{P}<0.01)$ (Table II ; Fig. 3).

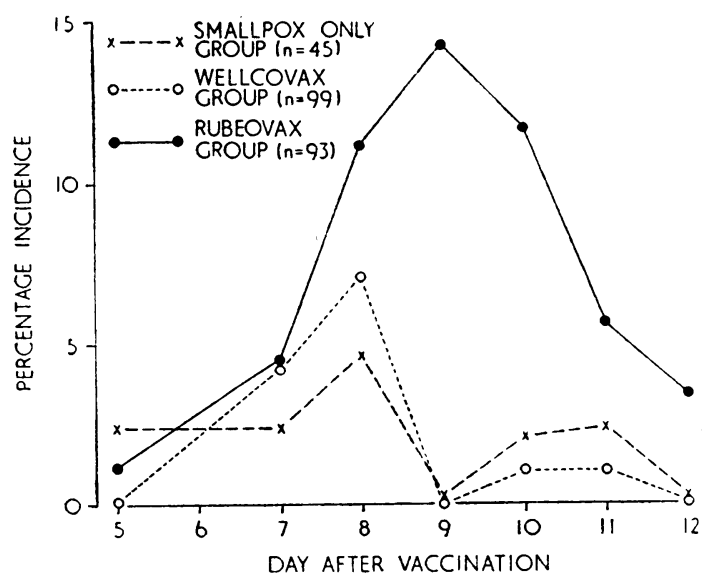

FIG 3.-Percentage incidence of fever of $103^{\circ} \mathrm{F} .\left(39.4^{\circ}\right.$ C.) and over.

4. The difference between pyrexias recorded in the Wellcovax group and the smallpox only group were not statistically significant $(\mathbf{P}>0.05)$.

5. There were 44 child/day attendances with fever of $103^{\circ} \mathrm{F}$. $\left(39.4^{\circ}\right.$ C.) and over out of $614 \mathrm{child} /$ day attendances among the Rubeovax group. Corresponding figures for the Wellcovax group were 13 out of 680 child/day attendances, and 6 out of 304 child/ day attendances for the smallpox only group. The difference between the Rubeovax group and the other two groups is highly significant $(\mathrm{P}<0.001)$

Treatment for children with fever of $103^{\circ} \mathrm{F} .\left(39.4^{\circ} \mathrm{C}\right.$.) and over was tepid sponging and aspirin. In the Rubeovax group 16 children required tepid sponging-one of them on four consecutive days, two on three consecutive days, two on two consecutive days, and the remainder on one occasion only. In the Wellcovax group eight children required tepid sponging, two of them on two consecutive days ; four children in the smallpox vaccine group required this treatment on one day only. The difference in the treatment rate between the Rubeovax group and the other two groups is significant at the $95 \%$ level of confidence.

\section{Clinical Findings}

Table III compares the incidence of various clinical reactions among the three groups. The significant finding in this Table is the higher proportion of children assessed as "unwell" in the Rubeovax group as compared with the other two groups $(\mathrm{P}<0.05)$.

\begin{tabular}{llll|c|c|c}
\multicolumn{8}{c}{ TABLE III. Clinical Reactions } \\
\hline
\end{tabular}

* S.E.D. between the Rubeovax group and the Wellcovax group $6.11 \quad(\mathrm{P}<0.05)$ + S.E.D. between the Rubeovax group and the Wellcovax group $5.53(\mathrm{P}<0.05)$ The reasons for an assessment of unwell are given in separate tables.

It will be noted that some of the conditions for which children were assessed as unwell were clearly not related to the vaccination procedure. Three of the 24 "unwells" in the Rubeovax group, 5 of the 11 in the Wellcovax group, and all four in the smallpox only group fell into this category (Table IV).

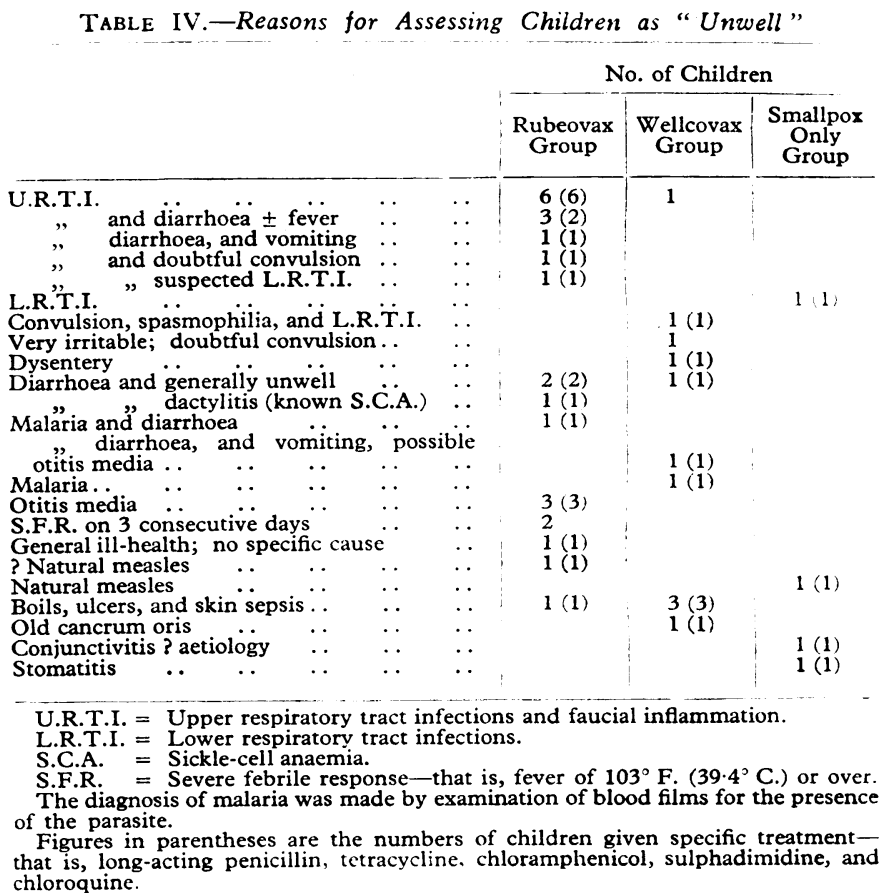


Faucial inflammation was observed in $31.2 \%$ of the Rubeovax group and in $16.2 \%$ of the Wellcovax group. No faucial inflammation was noted in the smallpox only group. The difference between the incidence of faucial inflammation in the Rubeovax and the Wellcovax groups was statistically significant $(\mathrm{P}<0.05)$.

A number of parents complained of "twitching" or " jerking" in their children, usually associated with high fever. Five in the Rubeovax group and three in the Wellcovax group complained of this symptom, but none in the smallpox only group. Careful questioning of the mothers of these children usually failed to elicit evidence of a true convulsion. It was concluded that these symptoms were a manifestation of restlessness associated with fever, and not genuine convulsions.

One patient in the Wellcovax group developed convulsions and tetany on the second day after vaccination and was later admitted to the Wesley Guild Hospital. This patient had received native medicine. Spasmophilia persisted for several days. The patient responded slowly to treatment with calcium gluconate and sedatives. He was given antibiotics for a respiratory infection which developed in hospital, and recovered completely. The nature of the symptoms in this patient and their time of onset suggest that this illness was incidental and not related to vaccination.

\section{Response to Smallpox Vaccination}

The incidence of successful primary vaccinations was $97.8 \%$ in the Rubeovax group, $96.9 \%$ in the Wellcovax group, and $100 \%$ in the smallpox only group (Table III). From questioning the mothers it seems likely that at least two of the children who failed to "take" may in fact have missed their smallpox vaccine injection. There were only five children who failed to "take" and four of them were aged 2 or more. There was no evidence of significant interference between the measles and smallpox vaccines.

The great majority of children developed lesions of $1 \mathrm{~cm}$. or less in diameter which showed the classical characteristics of primary vaccination.

\section{Antibody Responses to Measles Vaccination}

Antibody responses determined on paired serum samples by the haemagglutination inhibition method (Hendrickse et al., 1966b) gave the following results:

Rubeovax Group.-There were 80 paired serum samples, of which $6(7.5 \%)$ showed antibodies in the first sample. Of the 74 initially nonimmune children $93.2 \%$ showed satisfactory antibody conversions. The geometric mean titre of the postvaccination samples was 140 .

Wellcovax Group.-There were 91 paired serum samples, of which $10(11.0 \%)$ showed antibodies in the first sample. Of the 81 initially nonimmune children $87.6 \%$ showed satisfactory development of measles antibody. The geometric mean titre of the postvaccination samples was 89 .

\section{Discussion}

Findings in this trial clearly show that clinical reactions to simultaneous measles and smallpox vaccination are more frequent and severe with attenuated measles vaccines than with further attenuated measles vaccines. The differences observed in temperature responses and "unwell " rates in the two measles vaccine groups in this trial are statistically significant.

Serological findings, on the other hand, confirm that both measles vaccines used are effective immunizing agents. The overall antibody conversion rates were similar in the two measles vaccine groups. The difference observed in the geometric mean titres of measles antibody in the postvaccination bloods between the attenuated and further attenuated measles vaccine groups accords with findings reported in other trials in which these vaccines were compared. It has not been demonstrated to date that the difference in geometric mean titres achieved by the two classes of live measles vaccine reflects a difference in the protection afforded against the disease.

The subjects in this trial were selected healthy children who were protected from malaria during the period of the trial. It can be anticipated that reaction rates in unselected groups of children not protected from malaria will probably be somewhat higher than those recorded here. We expect, therefore, that if mass measles plus smallpox vaccination is undertaken in Nigeria with attenuated measles vaccine significant reactions will be provoked in more than $30 \%$ of the children vaccinated.

Our findings in this respect are similar to those observed in a combined measles plus smallpox vaccination study undertaken recently in Togoland (Budd et al., 1965). If, on the other hand, mass vaccination is undertaken with further attenuated measles vaccine the anticipated incidence of significant reactions will be in the region of approximately $10 \%$. This reaction rate is very similar to that observed in our group of children who received only smallpox vaccine.

Medical services in developing countries could easily be disorganized by a sudden general increase in demands for medical attention by a section of the population. If mass measles plus smallpox vaccination were undertaken in such countries it must be anticipated that in the immediate postvaccination period there would be an increased demand for medical attention. The size of this increase would be directly proportional to the reactogenicity of the vaccines employed. In the light of our experience it can be estimated that the use of attenuated measles vaccines will create at least a threefold greater demand for medical attention than the further attenuated measles vaccines.

Our findings indicate that simultaneous measles and smallpox vaccinations on a large scale would be a justifiable procedure if further attenuated measles vaccine strains were used.

\section{Summary}

The need for a trial comparing the attenuated and further attenuated measles vaccines given simultaneously with smallpox vaccine is discussed.

A comparative trial of attenuated measles vaccine given simultaneously with smallpox vaccine, further attenuated measles vaccine with smallpox vaccine, and smallpox vaccine given alone is reported. Clinical assessment of 237 children showed that those who received attenuated measles vaccine plus smallpox vaccine had significantly higher fever and morbidity rates than those given either further attenuated measles vaccine plus smallpox vaccine or smallpox vaccine alone. The measles antibody responses in initially susceptible children were satisfactory in both groups given measles vaccine. The incidence of successful primary smallpox vaccinations was between 97 and $100 \%$ in all groups. The results of this trial show that a further attenuated measles vaccine given simultaneously with smallpox vaccine would be preferable to an attenuated measles vaccine given with smallpox vaccine in a developing country.

We wish to thank the Permanent Secretary, Ministry of Health, Western Provinces of Nigeria, for permission to carry out this trial His Highness the Apetu of Ipetu for securing the co-operation of the local population and the help and hospitality of the staff of the Save the Children Fund organization at Ilesha, without which the trial could not have been undertaken. We are grateful to the medical superintendent and the laboratory, nursing, and auxiliary staff of the Wesley Guild Hospital, Ilesha, for their co-operation, 
and the departments of University College Hospital, Ibadan, who gave their assistance.

The Wellcome Foundation kindly supplied the vaccines and the needleless injectors used in this trial.

Reprints of this paper will be available from Professor R. G. Hendrickse, Department of Paediatrics, U.C.H., Ibadan, Nigeria.

\section{REFERENCES}

Budd, M. A., Scholtens, R. G., McGehee, R. F., jun., and Gardner, P (1965). Presented to the American Public Health Association's 93rd Annual Meeting, Chicago, Illinois.

Collard, P., Hendrickse, R. G., Montefiore, D., Sherman, P., Van Der Wall, H. M., Morley, D., Goffe, A.' P., Lawrence, G. D., and Pollock, T. M. (1961). Brit. med. f., 2, 1246.

Daily Times, 6 July 1966. Lagos, Nigeria.

Du Pan, R. M. (1965). Bull. Wld Hlth Org., 32, 331.

Gans, B., Macnamara, F. N., Morley, D. C., Thomson, S. W., and Watt, A. (1961). W. Afr. med. f., 10, 253.

Hendrickse, R. G., Montefiore, D., Peradze, T., Sherman, P. M., and Powell, M. (1966a). f. trop. med. Hyg., 69, 112.
779.

- - and Sofoluwe, G. O. (1965). Bull. Wld Hith Org., 32, 803.

470 .

- and Sherman, P. M. (1965). Arch. ges. Virusforsch., 16, 27.

Krugman, S. (1965). Arch. ges. Virusforsch., 16, 339.

Meyer, H. M., jun., Hostetler, D. D., jun., Bernheim, B. C., Rogers, N. G., Lambin, P., Chassary, A., Labusquière, R., and Smadel, J. E. (1964). Bull. Wld Hlth Org., 30, 783

Morley, D. (1964). Proc. roy. Soc. Med., 57, 846.

Woodland, M., and Martin, W. J. (1963). F. Hyg. (Lond.), 61, 115.

New Nigeria, 2 July 1966. Kaduna, Nigeria.

Rey, M., Baylet, R., Cantrelle, P., Dauchy, S., Diop Mar, I., and Guérin, M. (1965a). Bull. Soc. méd. Afr. noire Langue franç., 10, 392.

Diop Mar, I., and Cantrelle, P. (1965b). Arch. ges. Virus forsch., 16, 260.

Smorodintsev, A. A., Boychuk, L. M., Shikina, E. S., Meshalova, V. N., Taros, L. Y., Aminova, M. G., Revenok, N. D., and Safarov, D. I. (1965). Ibid., 16, 284.

W.H.O. (1963). Wld Hlth Org. techn. Rep. Ser., No. 263.

- (1964). Ibid., No. 283.

\title{
Intestinal Hormones and Plasma Insulin: an Insulinotropic Action of Secretin*
}

\author{
D. R. BOYNS, $\dagger \ddagger$ M.B., B.SC., M.R.C.P. ; R. J. JARRETT, $\dagger$ M.A., M.D. ; H. KEEN, $\dagger$ M.B., M.R.C.P.
}

Brit. med. J., 1967, 2, 676-678

McIntyre, Holdsworth, and Turner (1964) and Elrick, Stimmler, Hlad, and Arai (1964) demonstrated the greater effect of oral glucose administration, compared with intravenous, in stimulating a rise in plasma insulin levels. McIntyre, Holdsworth, and Turner (1965) presented evidence that the augmentation of the response was due to the release of a hormone from the gut wall. At present there are two obvious candidates for this role-secretin and glucagon (Lancet, 1966). We have already published evidence that there is no rise in fasting venous plasma immunoreactive insulin levels when endogenous secretin release is stimulated by intraduodenal instillation of acid (Boyns, Jarrett, and Keen, 1966). In this paper we report further studies of the effect of endogenous secretin on the plasma immunoreactive insulin response to intravenous glucose. In addition, the effects of purified porcine secretin have been studied and compared with those of purified cholecystokinin/pancreozymin.

\section{Materials and Methods}

Endogenous secretin was stimulated by intraduodenal infusion of $0.05 \mathrm{~N}$ citric acid ( $p \mathrm{H} 2.5$ ), $5 \mathrm{ml} . /$ minute for alternate minutes over 20 minutes. Purified secretin $(20,000$ clinical units/mg.) and purified cholecystokinin/pancreozymin -referred to subsequently as C.C.K.-(1,500 Ivy dog units/ mg.) were obtained from Professor J. E. Jorpes and Dr. V. Mutt ; $6 \mu \mathrm{g}$. of secretin or $50 \mu \mathrm{g}$. of C.C.K. was made up in $20 \mathrm{ml}$. of physiological saline and injected intravenously at a rate of $1 \mathrm{ml} . /$ minute.

\footnotetext{
* Based on a communication to the Medical and Scientific Section of the British Diabetic Association, 30 September 1966.

† Department of Medicine, Guy's Hospital, London S.E.1.

$\ddagger$ Present address: Arlais, St. Ishmaels Road, Kidwelly, Carms.
}

Intravenous infusions of $5 \%$ glucose were administered at a rate of $20 \mathrm{~g}$. of glucose per hour. Preliminary experiments had shown that this rate of infusion provoked only a small and slow rise in plasma immunoreactive insulin levels. When two infusions were given on the same day, two hours elapsed between the end of the first and the beginning of the second infusion.

Blood samples were taken into heparinized tubes from an indwelling polyethylene cannula placed in an antecubital vein. Then $0.1 \mathrm{ml}$. was transferred to $3 \mathrm{ml}$. of $1 \%$ potassium fluoride for subsequent estimation of blood sugar on an autoanalyser, the method of Hoffman (1937) being used. Plasma was separated by centrifugation and was assayed for insulin by a double antibody precipitation method similar to those described by Morgan and Lazarow (1963) and Hales and Randle (1963).

All the experiments reported were performed in the morning. after an overnight fast, on five healthy men aged $25-40$, who lay at rest during the experimental period. All had normal oral glucose tolerance.

\section{Results}

In three subjects the blood sugar and plasma immunoreactive insulin response to intravenous glucose infusion was measured with an intraduodenal tube in position. In the control infusion, intraduodenal infusion of physiological saline, $5 \mathrm{ml}$. per minute for alternate minutes, was carried out for the first 20 minutes of the glucose infusion. The results were compared with a similar infusion of citric acid (Fig. 1). In none of the three subjects did the infusion of citric acid augment the response of the plasma immunoreactive insulin to intravenous glucose.

Secretin or C.C.K. was infused intravenously, alone (Fig. 2) and along with intravenous glucose (Fig. 3). In neither case 